\author{
Yevhen SAVELYEV, \\ Nataliya KOMAR, \\ Evangelos SISKOS, \\ Konstantia DARVIDOU
}

\title{
GREECE: \\ A EUROPEAN MECHANISM OF THE EXIT FROM THE CRISIS
}

\begin{abstract}
Historical aspects of the creation of European countries of the integration association - the EU are highlighted. Historical stages and reformation of the accession of the Greek economy to the EU are estimated. After the restoration of the democracy in Greece, the negotiations about its accession, which lasted three years (July 1976 - May 1979), were intensified again. January 1, 1981, Greece joined the European Community. Since the country's accession to the EU in 1981, GDP has grown substantially. Considering the level of inflation before and after the accession of Greece to the EU, by 1981, the inflation rate was gradually increasing, and after accession, particular in 2002, the inflation rate stabilized when Greece fully implemented the euro. Despite the GDP growth, the decline of the level of inflation, the Greek government carried out a thoughtless

(C) Yevhen Savelyev, Nataliya Komar, Evangelos Siskos, Konstantia Darvidou, 2019.

Savelyev Yevhen, doct. of econ. sciences, professor, Ternopil National economic university. Komar Nataliya, cand. of econ. sciences, Ternopil national economic university.

Siskos Evangelos, Technological Educational Institute of Western Macedonia, Greece. https://orcid.org/0000-0002-5221-4444.

Darvidou Konstantia, Technological Educational Institute of Western Macedonia, Greece. https://orcid.org/0000-0002-8113-7302.
\end{abstract}


populist policy, spending huge loans from the IMF on social welfare of the population. While the national industry required significant investments. That's why it's not surprising that, since 1981, Greece's national products turned out to be uncompetitive with European analogs in the context of liberalization of foreign trade, and its negative foreign trade balance more increased. Although the amount of export and import of goods and services at current prices between Greece and countries of the EU increased.

The decrease of labor productivity, lack of modernization measures of agriculture as a priority sector in Greece led to an increase in the budget deficit and the debt load of the Greek economy. In 2008, government revenues declined even more, which led to bankruptcy of enterprises and a large reduction of employees. Also the macrofinancial assistance to Greece over 2010-2018 for the sum of 288.7 billion euros for the exit from the debt crisis is considered. The implementation of three macrofinancial assistance programs required the Greek government to implement a series of reforms that should reduce the debt deficit and debt load. The last effects of loans of the IMF and the European Stabilization Mechanism are evaluated.

\section{Key words:}

European integration, European Union, GDP, inflation, external debt, exports, imports, global financial crisis, macrofinancial assistance, IMF, European stabilization mechanism, Eurozone countries.

JEL: F02.

\section{Introduction}

The European Union was created not only at one time by the Maastricht Treaty but was the result of gradual integration since May 9, 1950, when one level of the Union gave confidence and an incentive to create the next level. Thus, the EU was created on the demands of its member states. It should be noted that each country at accession to the EU pursued its own economic and political interests and expected to achieve certain structural changes in the economic and social spheres, in external activity and the activation of the movement 
of capital and labor. In order to assess the motives and consequences of European integration in the context of the EU, we chose the Mediterranean country Greece, which joined the European Community on January 1, 1981, becoming the tenth member state of the European Community and demonstrated the second wave of EU expansion. On the example of the Greek economy, we will be able to consider the historical preconditions for the country's accession to the EU, to analyze what macroeconomic results were achieved by Greece under the conditions of the EU, and to assess the causes and consequences of Greece's debt crisis and the European mechanism for its exit.

\section{Analysis of the recent research and publications}

The history, stages of the formation of the EU and the effectiveness of European integration, including the accession of Greece to the EU, were studied by such scientists as Savelyev E., Burakovsky I., Kopiyka V., Kudryavtsev K.A., Shynkarenko T., E. Siskos, T. Giannitsis, K. Mattas, V. Tzouvelekas, M.G. Plummer, Rebecca M. Nelson, Paul Belkin, Derek E. Mix, Miranda Xafa, Jan van der Harst, Jan Suchaček, Enrico Spolaore, Weiler and Martina Kocjan, Elizabeth Mariotz, D.K. Malhotra and others.

It should be noted that many studies focus on the reasons for the establishment of the EU and the institutional maintenance of its functioning, including the objectives, preconditions and motives for the accession of the European continent countries to the European community, and also on the consequences of European integration as a whole. At the same time, the studies of Ukrainian scholars paid little attention to European integration and its historical peculiarities in terms of countries (for example, Greece), as well as the achievements of Greece and its losses due to ineffective internal policy of the country.

\section{Formulation of the problem}

The main purpose of the article is to define goals, motives and preconditions, based on a retrospective analysis, the integration of the Greek economy into the European community, and the study of the causes and consequences of Greece's fiscal debt crisis and its exit mechanisms. 


\section{Main material}

European integration was caused by historical circumstances and motivated by policy, economic and security discussions: to avoid repeating government failures that took place during the two World Wars in the 20th century and the spread of nationalism; economic devastation caused by the ravage of the war; the emergence of two world leaders on the world stage - the United States and the Soviet Union with competitive economic and political ideologies; the division of Europe (Western and Eastern) and the need for security from the threats and expansion of the Soviet Union; the need for the rapid development of living standards and economic transformations with a view to establishing lasting peace and security and preventing fascism and communism; the reconciliation of France and Germany as the basis of stability inside Western Europe (Komar N.V., 2015, pp. 118-120).

As world and European practice shows positive changes begin in countries that became members of certain integration associations, such as: accelerating of the economic growth, reducing of inflation, increasing of the social protection of the population, reducing unemployment, etc. This situation is characterized by the term "demonstration effect», which manifests itself in the fact that positive developments in member states of a certain regional integration association, including the EU, have a great psychological impact on those countries that are beyond its borders. They are trying to integrate and become a full member without even having the macroeconomic preconditions for this.

Countries that stay out the regional integration association basically feel some difficulties in dealing with countries that are members of the association. This is the so-called "domino effect», which requires the country to join the integration association more quickly in order to improve and increase the volume of foreign trade between partners within the framework of the integration association (Komar, 2015, pp. 68-79 et.al).

The theory of the causes and consequences of international integration will help us to understand more deeply the reasons and motives under the conditions of a retrospective analysis of Greek integration into the EU and to analyze how much the expectations of the Government and the population of Greece coincide with the results of European integration of the country. Greece's path to a single Europe was not simple and fast. Greece's cooperation with European countries on its integration into the European community began in the 50s of the twentieth century. The basis of the negotiations between Greece and the EU countries were the principles of the Agreement on Associative Membership. During the transition period of the integration processes in Greece, which was quite significant, the Greek government was able to prepare its political and social system to the requirements of the EU. 
In June 1959 this country submitted an application for accession to the European Economic Community (EEC). In 1961 an Association Agreement between Greece and the European Economic Community was concluded. In subsequent years there was a partial suspension of the integration processes of Greece with the European countries, and in April 1967 - complete freezing after the beginning of dictatorship in Greece. Only since July 24, 1974, after the restoration of democracy, the negotiations of Greece and EU were intensified again. On July 12, 1975, Greece again applied for membership of the EU. Negotiations on accession lasted almost three years (July 1976 - May 1979), which resulted to the signing of the Treaty on the Accession of Greece to the European Community and ratified by the Greek Parliament on May 28, 1979. Official accession of Greece to the European Community was in two years after that (January 1, 1981).

The main preconditions and motives of Greece's accession to the European community should be highlighted, such as:

- ensuring political stability in the country and promoting the development and modernization of the Greek economy and society;

- improving the living standards of the population;

- reduction of crime rate in the country;

- strengthening independence and position within the regional and international systems, developing its relations with other international members outside the EU;

- increasing influence on the process of European integration, and also on the configuration of the European model;

- the attractiveness for the Greeks to belong to the «European family». (Siskos, 2009).

Considering the Greek economy before accession to the European Union, it should be noted that the Greek economy from 1950 to 1973 was in a high pace of economic and social development. There was the so-called Greek economic miracle, which was characterized by high rates of economic growth in the country (on average, this indicator reached 7\%), which was the second in the world after Japan during the same period. The gross domestic product of the state increased each year (Fig. 1).

After the accession of Greece to the EU, there was a further intensive GDP growth, which lasted until 2008. 
Fig. 1

GDP of Greece during the period 1960-1980, billion dollars

(Kudryavtsev, 2014)

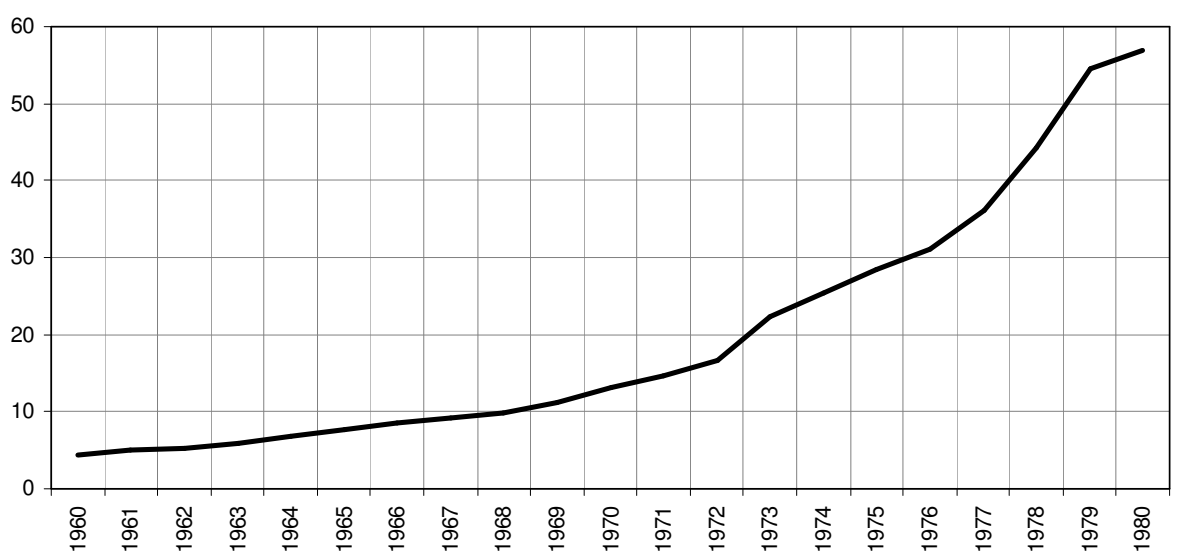

Fig. 2

GDP of Greece during the period of 1981-2016, billion dollars

(Greece: EU membership experience)

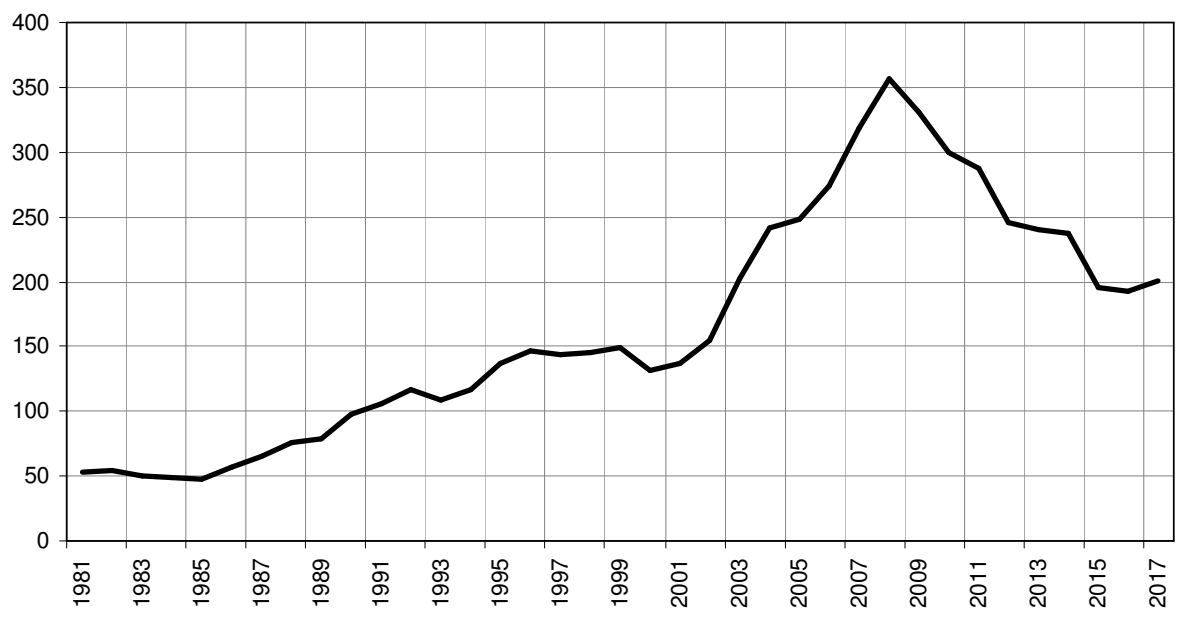


Greece's accession to the Eurozone in January 2001 and the transition to the euro significantly simplified the process of getting loans for the Greek government. This was explained by the fact that the profitability from Greek bonds and interest rates declined sharply, because Greek membership in the European Union significantly reduced the risks for potential borrowers. As a result, the real GDP growth was an average of $3.9 \%$ per year between 2001 and 2008, the second fastest after Ireland in the Eurozone.

Considering the level of inflation before and after the accession of Greece to the EU, we can highlight the fact that by 1981 inflation was gradually increasing (Fig. 3).

Fig. 3

Inflation rate of Greece in the period 1960-1980, \%

(Kudryavtsev, 2014 et.al)

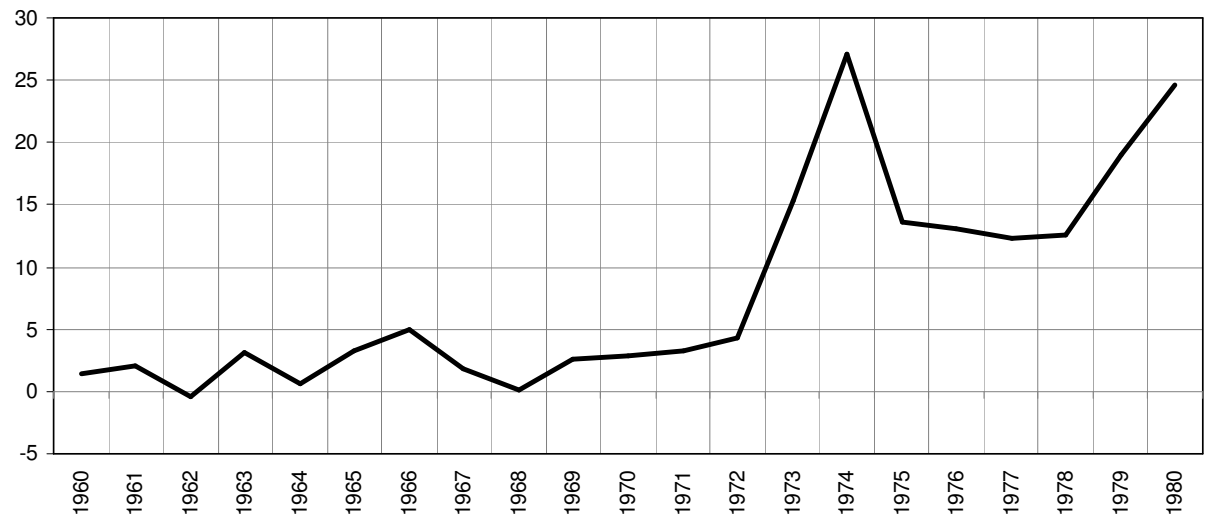

After the accession of Greece to the EU, the inflation rate began to fall, because Greece became part of the European market. The stabilization of the inflation rate was in 2002, when Greece fully implemented the euro, which was already controlled by the European Central Bank (Fig. 4). 
Fig. 4

The level of inflation in Greece in the period 1981-2016, \%

(Greece: EU membership experience et.al)

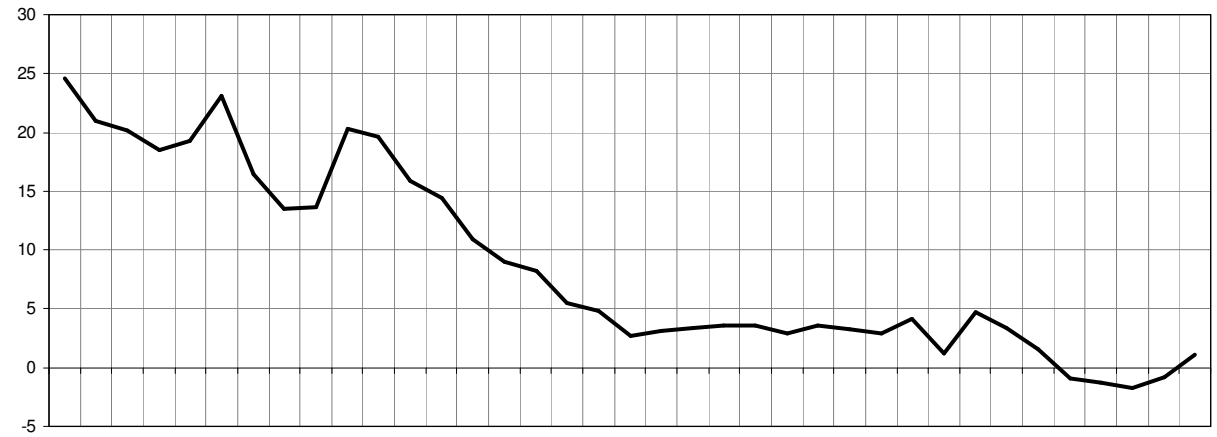

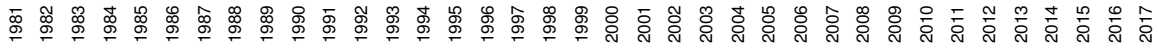

Having received new opportunities, the Greek government has begun a series of reckless steps in obtaining huge IMF loans for social security. According to Eurostat, from 2002 to 2007, costs on Greek social articles grew by $200 \%$ (Greece: EU membership experience et.al). As a result of this policy, the share of services in the GDP of Greece increased from $62 \%$ (1996) to $75 \%$ (2009), and the share of industry declined significantly. At the initial stage, loans from the IMF provided a fairly high level of income for the majority of the population of Greece, and this policy has benefits for both the Greeks and the government.

As a result, it led to low productivity, reduced competitiveness and unbridled tax evasion, which led to an increase in the budget deficit and debt burden of the Greek economy. It should be noted that the ratio of Greece's debt to GDP in 2000 was $103 \%$, which significantly exceeded the maximum allowed level of the Eurozone $-60 \%$. The same was about Greece's state deficit. The ratio of the state budget to GDP in 2000 was $3.7 \%$, exceeding the $3 \%$ limit for the euro Eurozone. In 2009, the state deficit reached a critical indicator - almost $16 \%$ of GDP. Failure to comply with the Maastricht criteria for Greece's accession to the Eurozone has had negative consequences. 
Vol. 18. № 1 (68). January-March 2019

ISSN 2519-4070

Fig. 5

External debt of Greece, individual EU countries

and Eurozone by the end of 2017

(Statistical data of the International Monetary Fund)

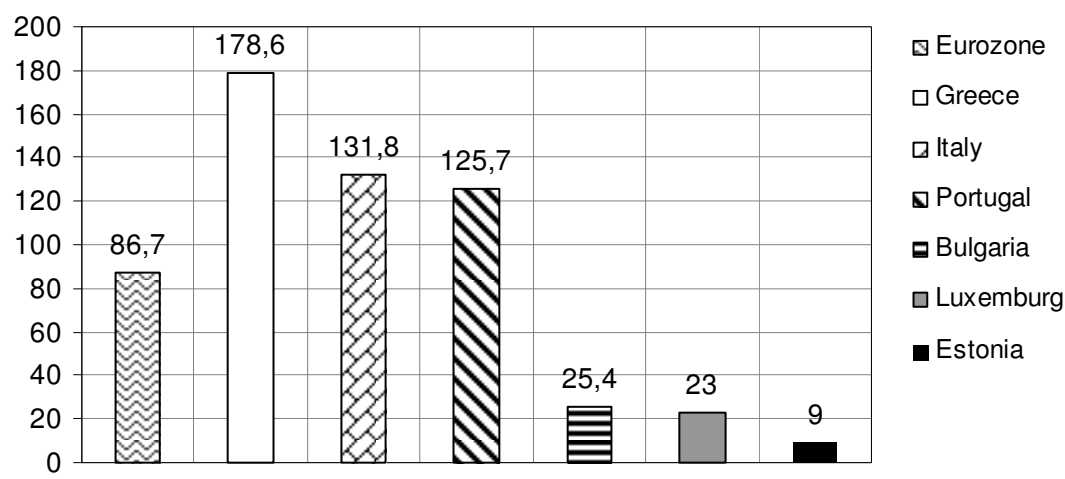

Fig. 6

Budget deficit of Greece in relation to GDP, \% (Greek Government Budget)

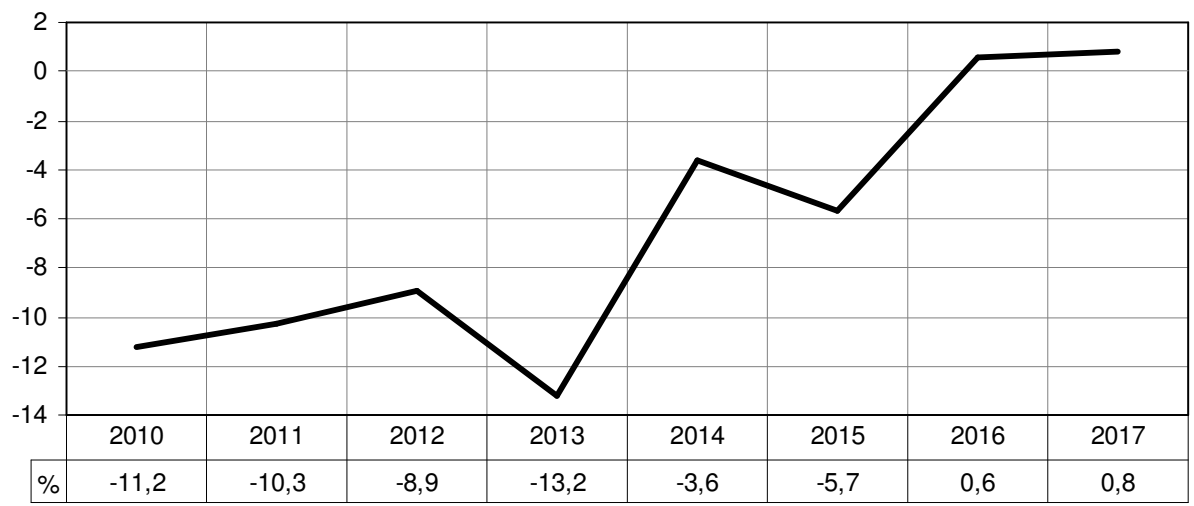


If we consider the reason of the formation of a double deficit, we should pay attention to the dynamics of the deficit of trade in goods and services as the main component of the current account of the balance of payments and the budget deficit (Table 1). We see that the problem of a double deficit actually arose long before the crisis of 2008. Almost equally the source of the trade deficit was the increased demand for imports from the private and public sectors. The decline in the trade deficit was faster during the crisis due to reduced demand for imports. At the same time, the first response to the crisis was an increase in the state budget deficit to $15 \%$ in 2009. Since the crisis, the budget deficit has been a major factor in the trade deficit. In 2014, the budget deficit was cardinally reduced, and from 2016 the problem of a double deficit was almost solved. In 2000-2017, the correlation between the trade and the state budget was 0.40 .

Table 1

The dynamics of the balance of foreign trade and the state budget of Greece

\begin{tabular}{|c|c|c|c|}
\hline Year & $\begin{array}{c}\text { Trade balance, \% } \\
\text { to GDP }\end{array}$ & $\begin{array}{c}\text { Budget balance, } \\
\% \text { to GDP }\end{array}$ & $\begin{array}{c}\text { Correlation of } \\
\text { budget balance } \\
\text { and trade bal- } \\
\text { ance, } \%\end{array}$ \\
\hline 2000 & -9.9 & -4.1 & 41 \\
\hline 2001 & -10.8 & -5.5 & 51 \\
\hline 2002 & -10.7 & -6.0 & 56 \\
\hline 2003 & -11.8 & -7.8 & 66 \\
\hline 2004 & -8.5 & -8.8 & 103 \\
\hline 2005 & -8.0 & -6.2 & 78 \\
\hline 2006 & -10.5 & -5.9 & 56 \\
\hline 2007 & -12.7 & -6.7 & 53 \\
\hline 2008 & -12.2 & -10.2 & 84 \\
\hline 2009 & -10.0 & -15.1 & 150 \\
\hline 2010 & -8.3 & -11.2 & 135 \\
\hline 2011 & -6.3 & -10.3 & 164 \\
\hline 2012 & -3.8 & -8.9 & 233 \\
\hline 2013 & -3.3 & -13.2 & 396 \\
\hline 2014 & -3.0 & -3.6 & 121 \\
\hline 2015 & -1.6 & -5.6 & 361 \\
\hline 2016 & -0.6 & 0.5 & -83 \\
\hline 2017 & -0.8 & 0.8 & -94 \\
\hline
\end{tabular}

Authors' data and calculations based on sources: Greece Government budget deficit; Hellenic Statistical Authority. 
Fig. 7

\section{Balance of foreign trade and the state budget of Greece,} in the period 2010-2017

(Greece Government budget deficit et.al; Hellenic Statistical Authority et.al).

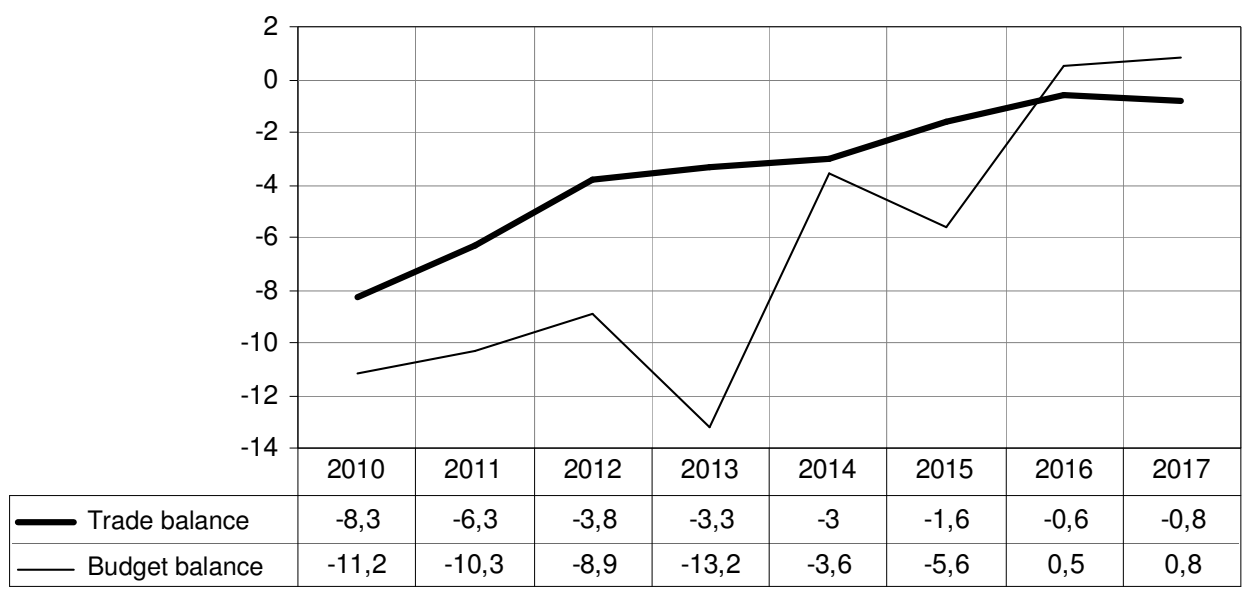

As the macroeconomic indicators were improved, in a few years, the path from the maximum profitability of 10-year government bonds was $48.6 \%$ in March 2012 to $4.26 \%$ on November 30, 2018. From mid-2010 through mid-2013 and in the first half in 2015, the profitability was higher than $10 \%$ (Greece Bond $10 Y)$. In such conditions, involvements from EU and the IMF funding mechanisms were practically inevitable.

In case of Greece's crisis, the correlation of yield with the budget deficit was the largest with a lag of 2 years (0.73). During this time, budget deficit had the greatest promotion to the growth of state debt. Using these data, we can also build a model for the profitability of government bonds in 2000-2017 with a determination coefficient of 0.59 :

$$
\operatorname{Ln}(D)=0,77+0,14 \mathrm{DB} \text {, }
$$

where $\mathrm{D}$ is profitability of 10 -year government bonds, \%; DB is deficit of the state budget, \% of GDP. This emphasizes the importance of balancing the budget for preventing a situation in which the rising cost of public debt servicing with time leads to an even larger budget deficit.

In 2008, during the crisis, it became clear that the previous model of development, based on excessive consumption and double deficit (state budget 
and balance of payments), has exhausted itself. In 2009, at the EU level, an excessive deficit procedure for Greece was initiated, and credit ratings declined. At the same time, initially, the EU did not provide a mechanism to help countries in the Eurozone, it was formed only later. In 2010, Greece faced a situation where the growth of government bond yields made it practically impossible to finance a budget deficit by placing debt obligations on the market. This has caused the request for financial assistance to the European Commission, the ECB and the IMF.

Starting from the fourth quarter of 2008, Greece faced a risk of default and exit from the Eurozone. The EU and the IMF have developed a financial rescue program for Greece, and from 2010 to august 2018 the country received preferential loans of 288.7 billion euro, of which 32 billion were from the International Monetary Fund, and the rest were from countries of Eurozone.

During this period, the Eurozone countries adopted three different threeyear assistance programs, but the first two were not finalized, and the third aid program ended on August 20, 2018. In exchange for the tranches received, the Greek government committed itself to implement strict measures of budgetary saving, to launch a privatization mechanism, to reduce pensions and social payments. The Greek government, at the request of international creditors, implemented pension and tax reforms, which leaded to the reduction of pensions, while taxes have risen substantially.

Table 2

EU-IMF assistance to Greece, Ireland and Portugal

(Rebecca M. Nelson, Paul Belkin, Derek E. Mix, 2011, August)

\begin{tabular}{|l|c|c|c|c|}
\hline Countries & $\begin{array}{c}\text { Date of finan- } \\
\text { cial assistance }\end{array}$ & $\begin{array}{c}\text { Financial as- } \\
\text { sistance from } \\
\text { the euro area } \\
\text { countries }\end{array}$ & $\begin{array}{c}\text { IMF financial } \\
\text { assistance }\end{array}$ & $\begin{array}{c}\text { Financial assis- } \\
\text { tance from the } \\
\text { euro area coun- } \\
\text { tries and the IMF }\end{array}$ \\
\hline Greece & May 2010 & $\begin{array}{c}80 \text { billion } \\
\text { euros }\end{array}$ & $\begin{array}{c}30 \text { billion } \\
\text { euros }\end{array}$ & $\begin{array}{c}110 \text { billion } \\
\text { euros }\end{array}$ \\
\hline Ireland* & December 2010 & $\begin{array}{c}45 \text { billion } \\
\text { euros }\end{array}$ & $\begin{array}{c}22,5 \text { billion } \\
\text { euros }\end{array}$ & $\begin{array}{c}67,5 \text { billion } \\
\text { euros }\end{array}$ \\
\hline Portugal & May 2011 & $\begin{array}{c}52 \text { billion } \\
\text { euros }\end{array}$ & $\begin{array}{c}26 \text { billion } \\
\text { euros }\end{array}$ & $\begin{array}{c}78 \text { billion } \\
\text { euros }\end{array}$ \\
\hline
\end{tabular}

* In other reports, Ireland's financial assistance amounted to 85 billion euros, including 17.5 billion euros of Irish reserves and other liquid assets. 
The aforementioned countries from Table 2 which were in a similar situation as Greece, managed to stabilize the situation, after receiving financial assistance. Thus, Portugal, which in 2011 received 78 billion euros under the same scheme as Greece, significantly reduced public spending by 2014 . Following the completion of the financial assistance program, the Government of Portugal has abandoned austerity, managed to achieve economic growth to a record-breaking figure for two decades, and as a result returned the salaries to public employees and pensions to the pre-crisis level.

EU countries are trying to reduce budget deficits to an economically safe level $-3 \%$ of GDP according to the Maastricht criteria, so they are forced to cut budget expenditures, including social ones, and also increase the tax burden on the economy (Table 3).

Table 3

The expected budget level in countries of the world (estimated by the IMF) (Rebecca M. Nelson, Paul Belkin, Derek E. Mix, 2011, August, et.al)

\begin{tabular}{|l|c|c|c|}
\hline \multicolumn{1}{|c|}{ Countries } & $2015, \%$ & $2017, \%$ & Absolute deviation \\
\hline Japan & 6,4 & 5,2 & $-0,8$ \\
\hline USA & 5,6 & 5,4 & $-0,2$ \\
\hline EU & 2,2 & 1,0 & $-1,2$ \\
\hline Spain & 4,8 & 2,9 & $-1,9$ \\
\hline Slovenia & 4,1 & 3,6 & $-0,5$ \\
\hline Great Britain & 4,1 & 1,5 & $-2,6$ \\
\hline Ireland & 3,0 & 1,7 & $-1,3$ \\
\hline France & 3,0 & 1,3 & $-1,7$ \\
\hline Greece & 1,9 & 0,7 & $-1,2$ \\
\hline
\end{tabular}

In 2015 The Government of Portugal has cut budget expenditures by 1.4 billion euros (about $0.8 \%$ of GDP) at the expense of a reduction of expenses for maintain of central apparatuses of ministries, decrease of the number of employed in the State sector of the economy, also has raised taxes on capital and luxury goods, introduced new taxes on financial transactions.

The Spanish Government plans to reduce the share of public spending to GDP from $44.4 \%$ in 2014 to $40.1 \%$ in 2018 . The government also plans to cut unemployment benefits and some other social payments, to implement pension reform, reform of the labor market, introduce new special and environmental taxes. 

of the exit from the crisis

The Italian Government plans to cut budget spending by 26 billion euros and to continue the pension reform, which provides for an increase retirement age for women to 66 years old from 2018.

In 2012, the European Stability Mechanism was created by the euro-zone countries, which provided assistance to Greece, Spain and Cyprus. The program for Spain ended in 2014, for Cyprus - in 2016. In other words, the external financial support to Greece is the longest aid provided to the euro-zone countries after the international financial crisis. Thus, in August 2015, the euro-zone countries approved a third loan program for the Greek Government, for more than 80 billion euros, on the conditions of the Greek authorities adopting new harsh measures to reduce pensions, decrease of social payments and privatization of State property. However, in 2015, the new government, which came to power, refused to assistance and reforms. Six months later, the government had made concessions and, as a result, 61.9 billion euros were allocated in the framework of the third tranche for three years for macroeconomic stabilization and the recapitalization of Greek banks. The Fund notes that 24.1 billion euros, that were available to Athens for this program, were not useful.

Head of the European Stability Mechanism Klaus Regling noted that the completion of macro-financial assistance program to Greece does not mean the abolition of supervision by European partners, but on the contrary, supervision will be strengthened. External financing and a reform program allowed to keep Greek membership in the eurozone, albeit with losses, but all the same helped restore stability and economic growth, despite fears and political factors. The bases of the stabilization strategy were:

- receiving international financial assistance, prolongation of external loans with a decrease in interest rates, voluntary inclusion of the private sector in the exchange of bonds with a discount;

- gradual balancing of the state budget at the expense of reduction of expenses and expanding the tax base, including the introduction of a special property tax through the mechanism for paying bills for electricity;

- the restoration of export competitiveness by reducing prices and wages in the absence of the use of devaluation of the national currency;

- stabilization of the banking system by strengthening financial supervision, conducting stress-tests, an assessment of banks' loan portfolios, bank recapitalization, creation of temporary credit institutions within the framework of the restructuring of banking institutions, deposit guarantee, meeting the demand for cash;

- reform in the labor market and in the social insurance system; 
- privatization, restructuring of state enterprises;

- liberalization of markets.

At the same time, EU reforms aimed at creating common mechanisms for overseeing financial markets, budget policies of member countries, interventions of Eurosystem on the bond market, and easing requirements for assets that were used to provide refinancing of commercial banks were carried out.

However, the expected effect of recovery of the economy was not so fast, there were episodes of outflow of deposits. Balancing the budget was mainly achieved due to the growth of tax revenues, rather than cost reduction, that went counter to recommendations. In 2013, the first signs of stabilization appeared, the current account of the balance of payments became more stable, mainly due to reduction of imports, although government debt continued to grow (The chronicle of the great crisis the bank of Greece 2008-2013, 2014 року, September).

Although GDP fell by a quarter in 2008-2016, Greece managed to overcome the double deficit problem, restore the competitiveness of exports, although at the price of domestic devaluation by reducing wages, implement a range of reforms (health care, social insurance, tax system, labor market, public administration), consolidate the banking system and ensure a level of capital adequacy above the average European level, provide the growth of deposits, and improve the credit ratings of government bonds. In 2017, the difference between the interest rate on public debt and the growth of the economy became negative for the first time since the crisis $(-1.2 \%)$, that inspire optimism (Summary of the Annual report 2017, 2018, February). It became the basis for the recovery of the economy.

In 2019, economic growth is expected to be $2-2.3 \%$ and the primary budget surplus will be $3.5 \%$ of GDP. It is anticipated that in 2018, public debt reached its peak at $182.5 \%$ of GDP and will decline to $167.4 \%$ of GDP in 2020 (Greece Programme exit amid strengthening recovery).

The adoption by the Government of Greece of austerity measures aiming to reduce budget deficit, under the pressure of international lenders whose main goal was to save the country from a spontaneous default, has turned to the Greek labor market into bankruptcy of enterprises and large-scale reduction of employees. The unemployment rate in Greece is more than twice as high as the average unemployment rate in the euro-zone countries. In February 2013, this indicator was $10.8 \%$ for the 19 countries of the currency block. 
Table 4

Unemployment rate in Greece,\% (Greece - Unemployment rate)

\begin{tabular}{|c|c|c|}
\hline Years & Value, $\%$ & Change, $\%$ \\
\hline 2008 & 7,8 & $-7,74$ \\
\hline 2009 & 9,6 & 23,87 \\
\hline 2010 & 12,7 & 32,55 \\
\hline 2011 & 17,9 & 40,28 \\
\hline 2012 & 24,4 & 36,83 \\
\hline 2013 & 27,5 & 12,49 \\
\hline 2014 & 26,5 & $-3,55$ \\
\hline 2015 & 24,9 & $-6,04$ \\
\hline 2016 & 23,6 & $-5,42$ \\
\hline 2017 & 21,5 & $-8,92$ \\
\hline
\end{tabular}

Despite the growth of the economy, the standard of living has declined, the unemployment rate remains high - in $201721.5 \%$, but it is much lower than in 2013 , when it amounted to $28 \%$. Unemployment among young people has also dropped from $60 \%$ to $43 \%$. Although in the future, one in five of the able-bodied man in Greece remains unemployed. It is estimated that approximately 350-400 thousand educated and young Greeks emigrated from country with a population of 11 million people during the crisis in Greece. They have found jobs in other EU countries, and most of them are in no hurry to come back.

Considering the peculiarities of the trade environment, it should be emphasized that Greece has agreed to accept the various trading conditions and restrictions from the $\mathrm{EU}$, entering into the European trading space.

Absolute volumes of exports and imports of Greece have substantially increased in the conditions of Greece's stay in the EU. Thus, the exports of Greece at current prices increased by almost 7 times during the period of 1980-2017; the change took place at 0.30 billion U.S. dollars due to population growth of 2.5 million, and also by 57.4 billion U.S. dollars due to an exports growth per capita by $5,128.5$ U.S. dollars. The average annual export growth rate in Greece was at 1.3 billion U.S. dollars or $9.2 \%$. The average annual export growth rate in Greece at constant prices was $5.9 \%$. The share of Greece exports in the world increased by $0.013 \%$ and in Europe - by $0.17 \%$. In 1970 Greece exports was the minimum (1.0 billion U.S. dollars), in 2008 Greece exports was the maximum (82 billion U.S. dollars).

In 2008, the Greece imports amounted to 119 billion U.S. dollars. Commodity structure of Greek imports is as follows: machinery and equipment ac- 
count for only $38 \%$ of imports, industrial goods of general consumption $-25 \%$ of imports, food products $-13 \%$, raw materials $-12 \%$, fuel and lubricants $-12 \%$. Mainly, Greece imports from the following countries: Italy (17\%), Germany (16\%), USA (9\%), France (8\%), Great Britain (8\%), the Netherlands $(6 \%)$.

Table 5

Exports and imports of goods and services of Greece, billion U.S. dollars*

\begin{tabular}{|c|c|c|c|}
\hline Indicators/years & 1980 & 2008 & 2017 \\
\hline Exports & $\begin{array}{c}8 \text { billion } \\
\text { U.S. dollars }\end{array}$ & $\begin{array}{c}82 \text { billion } \\
\text { U.S. dollars }\end{array}$ & $\begin{array}{l}54 \text { billion } \\
\text { U.S. dollars }\end{array}$ \\
\hline Imports & $\begin{array}{l}11 \text { billion } \\
\text { U.S. dollars }\end{array}$ & $\begin{array}{l}119 \text { billion } \\
\text { U.S. dollars }\end{array}$ & $\begin{array}{l}56 \text { billion } \\
\text { U.S. dollars }\end{array}$ \\
\hline $\begin{array}{l}\text { Foreign trade } \\
\text { turnover }\end{array}$ & $\begin{array}{c}19 \text { billion } \\
\text { U.S. dollars }\end{array}$ & $\begin{array}{l}201 \text { billion } \\
\text { U.S. dollars }\end{array}$ & $\begin{array}{l}110 \text { billion } \\
\text { U.S. dollars }\end{array}$ \\
\hline $\begin{array}{l}\text { Foreign trade bal- } \\
\text { ance }\end{array}$ & $\begin{array}{c}-3 \text { billion } \\
\text { U.S. dollars }\end{array}$ & $\begin{array}{l}\text {-37 billion } \\
\text { U.S. dollars }\end{array}$ & $\begin{array}{c}-2 \text { billion } \\
\text { U.S. dollars }\end{array}$ \\
\hline
\end{tabular}

* compiled by the authors based on a source: (Greece: EU membership experience et.al)

Based on the foregoing, it can be concluded that the accession of Greece to the EU has led to a static effect, in particular to an effect of trade creation, which manifested itself in increasing consumption of imported goods by the Greek population and reducing national production, because national goods could not compete with European analogues.

It is no coincidence that many economists see a balance of payments crisis in the countries of the Mediterranean (Greece, Portugal, Spain, Italy) in the Greek crisis. Since the late 1990s, when the euro zone began to be formed, these countries took advantage of lower interest rates to finance growing consumption. As a result, in the countries of Southern Europe, consumer prices and wage costs began to rise much faster than labor productivity, thus outpacing the growth of labor costs in Germany and France. Therefore, balance of payments deficits sharply increased, and Greece has delivered the anti-record on this indicator not only among the euro zone countries, but also among the countries of the OECD (-10.4\% of GDP in 2010).

The productivity of labor in modern, "smart» and capital-intensive branches ceases to be determined by the actual time of work, and labor resources in lagging economies are distributed irrationally, in the conditions of scientific and technological progress. Thus, in Greece, the agrarian sector brings 
only $3.4 \%$ of national income, but it employed more than $12 \%$ of the country's labor force. The poor fuels and minerals base does not leave Greece the chance of success in a competitive struggle for international markets.

Greece systematically paid for growing imports of goods at the expense of new external loans, while the country practically did not receive foreign direct investment, and the investment by foreign investors in country's financial assets stocks and bonds - dropped sharply with the onset of the global economic crisis in 2008 .

Summarizing the above, we can conclude that the Greek economy is significantly behind the European leaders in terms of competitiveness and productivity.

In 1991, Plummer tried to quantitatively and qualitatively calculate the economic consequences of Greece's accession to the EU. The researcher discovered that during 1981-1991 Greece's trade turnover was positive due to the production of agricultural products, while trade diversification, in most cases, was caused by the production of manufactured goods and semi-finished goods (Plummer, 1991).

In 1988 Giannitis, exploring the «share of real consumption», found that the accession of Greece to the EU led to a significant increasing the share of imports of agricultural and industrial goods from the EU. He explained that the countries of the European Community implemented the Common Agricultural Policy (CAP) and minimized the impact of protectionist measures on consumer products (Giannitsis, 1988).

With the Integration Index, which was close to one, it was discovered that the dynamic effects of Greece's accession to the EU were minimal. Greece is not only a small country in comparison with the whole system of the European Union, but for the first time, a Customs Union was created by high-income developed countries and a middle-income country, such as Greece.

Researchers Mattas and Tzouvelekas (1999) believe that the accession of Greece to the EU has both a positive and negative impact on the economy of this country. In their view, the most important benefits are budgetary transfers from the EU, mainly due to the CAP, which has had a positive impact on farmers' incomes. The negative sides of Greek integration into the EU were trade liberalization, significant rising prices for agricultural products and domestic inflationary pressures, which in turn had a negative influence on the trade balance (Mattas, Tzouvelekas, 1999).

Exploring the investment environment, it is worth paying attention to the specifics of Greece's GDP, because this indicator affects the investment climate (Table 6). 
Vol. 18. № 1 (68). January-March 2019

ISSN 2519-4070

Table 6

GDP, GNP of Greece, billion U.S. dollars*

\begin{tabular}{|l|c|c|c|}
\hline Indicators/years & 1980 & 2008 & 2017 \\
\hline \multirow{2}{*}{ GDP } & 57,01 billion & 356,14 billion & 200,69 billion \\
& U.S. dollars & U.S. dollars & U.S. dollars \\
\hline \multirow{2}{*}{ GNP } & 138 billion & 331 billion & 289 billion \\
& U.S. dollars & U.S. dollars & U.S. dollars \\
\hline
\end{tabular}

* compiled by the authors based on a source: (Greece: EU membership experience et.al)

Before and after the accession of Greece to the EU, GDP had been growing steadily, which contributed to an increase in the flows of foreign investment in this country (Figure 8 ).

Fig. 8

Foreign direct investment in Greece during 2008 - 2017. (million euros) (Enterprise Greece)

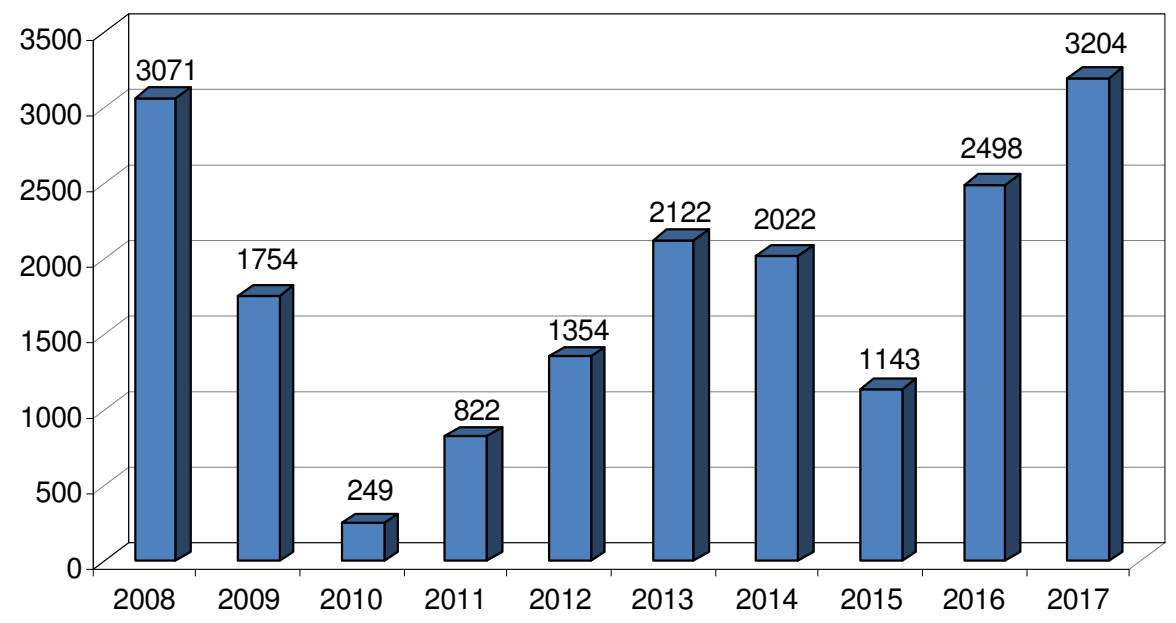



of the exit from the crisis

After 2008 there was a sharp decline in the inflow of foreign direct investment in the real sector of the Greek economy. In addition, the cost of raising loans for Greek enterprises was increased, and as a result it has led to a strong stagnation of the Greek economy in the next 10 years. However, it should be noted that in 2016 there was a substantial increase in investments in Greece, which gives positive expectations for further changes.

The accession of Greece to the EU also caused changes in the legal system of the country. Greece had to implement European legislation immediately after accession. Thus, from 1981 to 1985, the European Commission has initiated 108 proceedings, brought about by the incorrect application of EU norms and rules in Greece. There are still four areas in which the Greek and EU legal acts have some contradictions: ensuring the health and safety of employees in the workplace; the investments in the border regions; telecommunications and the banking sectors; determining the future of nationalized sectors of the economy (Greece: EU membership experience et.al).

Greece has moved from the ninth to third place in the EU poverty rate. Greece, Bulgaria and Romania have become the three poorest countries of the 28 ones of the European Union. After the crisis, all countries, except Greece, were able to reduce poverty to the average European level. In addition, the Greek economy is characterized by a bloated public sector, a mighty bureaucracy, weak institutional development and over-regulation of private business. In accordance with the Corruption Perception Index of Transparency International Greece had the highest level of corruption among all the eurozone countries in 2011. According to the World Bank, there is an overly large sector of the shadow economy in the country - in the period from 1999 to 2007 this indicator amounted to $27.5 \%$ of the official GDP on average.

\section{Conclusions}

From an economic point of view, Greece's accession to the EU in 1981 was a historic event, because it was the first time when the middle-income country joined the European community. Greece is a clear example of the fact that the accession to the European Union and eurozone accession has both positive and negative effects. Greece, having become part of the European community, had to accept the EU's conditions, taking into account all the risks of membership in the EU. The Greek Government pursued a policy based on populism - it was manifested in increasing spending on social needs of the population, instead of developing a national industry using EU loans. Therefore, the financial crisis of 2007-2008 has undermined the economy of Greece, which has led to job losses and large government debts. Impossibility of paying the external debts is accompanied by dissatisfaction of the local population, who protests against austerity 
policies from the side of international lenders. In addition, the private initiative in the country does not develop because of high bank interest and bureaucracy. The Greek economy is characterized by a high percentage of the public sector and the developed shadow economy.

Many scientists argue, that the modern Greek crisis is a consequence of Greece's accession to the EU, because the economic and political environment of Greece was not adapted to the restructuring.

The European Commission claims that the macro-financial assistance to Greece, during 2010-2018, from the IMF and the euro-zone countries helped the country become more economically strong. It is very difficult to predict further economic changes in Greece. However, many experts suggest two possible options for developing relations between Greece and the EU. The first option relates to cooperation with European lenders in terms of bringing Greece out of a long-term crisis. The current situation in the labor market shows that the level of unemployment is decreasing. At the same time, analysts believe that Greece will face a large number of unemployed again by 2020. It is expected the positive changes with a decrease in the level of inflation and government debt to GDP, along with a renewal of the national industry, which will bring the macroeconomic balance in the region. Skeptics are convinced that Greece will officially declare default much earlier than in 2023, if the economy of the country will be in depression, and private capital markets will not open for the government in the coming years. In this case, the only source of financing the budget deficit remains financial assistance from the European Union and the IMF, which obliges the Greek Government to implement tight budget reforms. This will in turn lead to popular riots and actions of civil disobedience, the coming to power of militant nationalists who will take an isolationist stance towards the European Union.

Another version speaks about Greece's exit from the eurozone and the return to a national currency. Proponents of such development of events argue that this situation will be able to stop the crisis in Greece and allow the government to independently manage its financial environment. The repeated devaluation of the national currency would allow the country to immediately increase its competitiveness by automatically reducing labor costs and rising profitability of the export sector. At the same time, it is anticipated that Greece's exit from the eurozone will lead to many adverse events for European states and will be a prerequisite for the late exit of Greece from the EU, which would be disastrous for the country itself.

\section{References}

1. Komar, N.V. (2015). Evolution of integration processes in Europe. Ukraine in the process of Association Agreement with the EU implementation: The col- 
lection of thesis of International scientific and practical internet conference of students and young scientists, pp. 118-120. (in Ukrainian).

2. Giannitsis, T., (1988), Accession to the EEC and Effects on Industry and Trade, Athens: Foundation for Mediterranean Studies.

3. Mattas, K., Tzouvelekas, V., (1999), The impact of EU Membership: Lessons from the Greek Experience, Economia Internazionale, pp. 173-181.

4. Komar, N.V. (2015). The free trade zone: evolution and effects for member states. Visnyk Ternopilskogo natsionalnogo universytetu, 1, pp. 68-79. (in Ukrainian).

5. Truman, E.M., (1975), «The Effects of European Economic Integration on the Production and Trade of Manufactured Products», in BALASSA, B., (eds), European Economic Integration, Amsterdam: North Holland, pp. 3-39.

6. Truman, E.M., (1969), «The European Economic Community: Trade Creation and Trade Diversion», Yale Economic Essays, 9:201-257.

7. Siskos, E. (2009) Global Strategies of European Integration. National Academy of Sciences of Ukraine. Publications Aston. Ternopil, 2008.

8. Kudryavtsev, K.O. (2014). Impact of crisis processes on the condition of macroeconomic equilibrium in Greek Republic. Economichnyy forum, 1, pp. 74-81. - Access mode: http://nbuv.gov.ua/UJRN/ecfor_2014_1_16. (in Ukrainian).

9. Greece: EU membership experience [Electronic resource]. - Access mode: http://osvita.ua/vnz/reports/international-relations/19216/. (in Ukrainian).

10. Rebecca, M. Nelson, Paul Belkin, Derek E. Mix (2011, August). Greece's Debt Crisis: Overview, Policy Responses, and Implications. Congressional Research Service for Congress,pp.1-19.

11. What has given Greece the membership in the European Union? [Electronic resource]. - Access mode: http://pravoslavnews.com.ua/massmedia/ Grecija_i_Evrosojuz/. (in Ukrainian).

12. Plummer, M. G., (1991), «Ex-Post Empirical Estimates of the Second Enlargement: The Case of Greece», Weltwirtschaftliches Archiv, 127:171181.

13. Statistical data of the International Monetary Fund [Electronic resource]. Access mode: imf.org. (in Ukrainian).

14. Greece Government Budget [Electronic resource]. - Access mode: https://tradingeconomics.com/greece/government-budget

15. Greece Government budget deficit [Electronic resource]. - Access mode: https://countryeconomy.com/deficit/greece

16. Hellenic Statistical Authority [Electronic resource]. -Retrieved from: ELSTAT 2018)A0702_SEL15_TS_AN_00_1995_00_2017_01_P_BI.XIsx 
17. Greece Government Bond 10Y [Electronic resource]. - Retrieved from: https://tradingeconomics.com/greece/government-bond-yield

18. The chronicle of the great crisis the bank of Greece 2008-2013 (2014, September). Public and institutional actions to safeguard financial stability and overcome the crisis. $-244 \mathrm{p}$.

19. Summary of the Annual report 2017 (2018, February). Bank of Greece / Presented to the general meeting of shareholders by governor Yannis Stournaras. $-49 \mathrm{p}$.

20. Greece Programme exit amid strengthening recovery [Electronic recource]. Retrieved from: ecfin_forecast_autumn_081018_el_en.pdf

21. Greece - Unemployment rate [Electronic resource]. - Access mode: https://knoema.com/atlas/Greece/Unemployment-rate

22. Enterprise Greece [Electronic recource]. - Retrieved from: https://www.enterprisegreece.gov.gr/en/greece-today/why-greece/foreigndirect-investment 